Institut für Veterinärpathologie

der Vetsuisse-Fakultät Universität Zürich

Direktor: Prof. Dr. med. vet. Andreas Pospischil

\title{
Immunohistochemical expression study of pro-apoptotic BH3-only protein Bad in canine non-neoplastic tissues and canine lymphomas
}

\author{
Inaugural-Dissertation \\ zur Erlangung der Doktorwürde der \\ Vetsuisse-Fakultät Universität Zürich
}

vorgelegt von

\author{
Martina Andrea Dettwiler \\ Tierärztin \\ von Reigoldswil BL, Schweiz
}

genehmigt auf Antrag von

Prof. Dr. med. vet. Franco Guscetti, Referent 


\section{Inhaltsverzeichnis}

Abstract

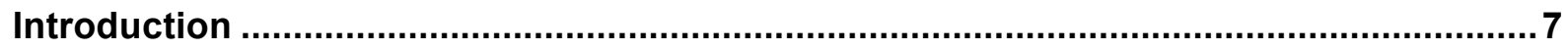

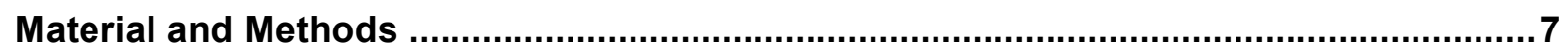

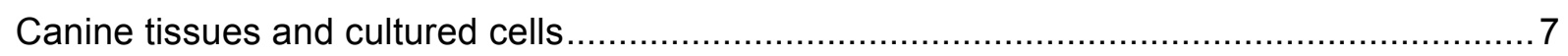

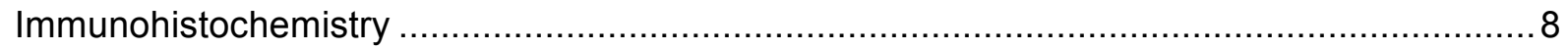

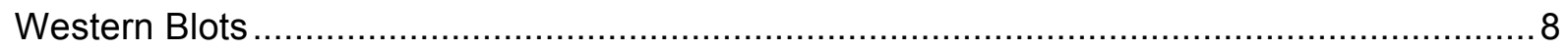

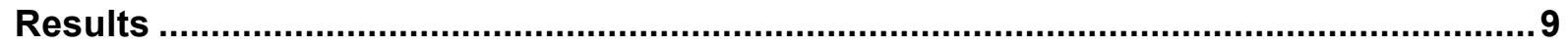

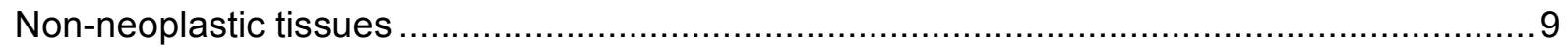

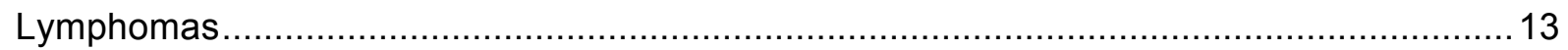

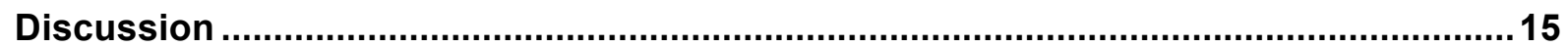

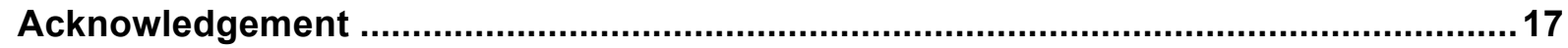

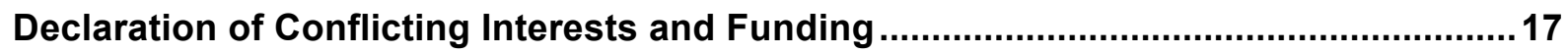

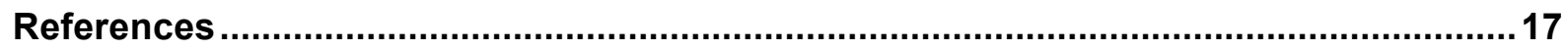

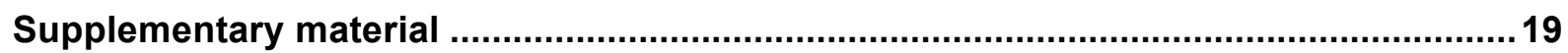

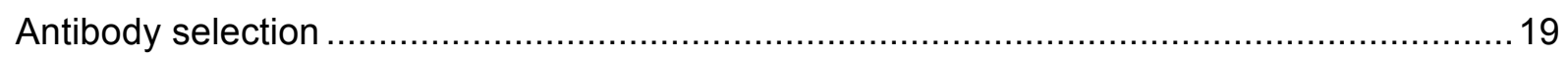

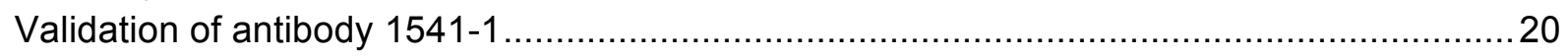

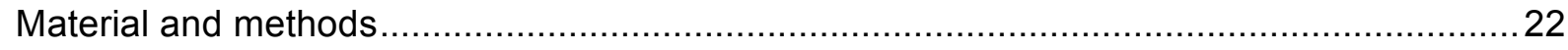

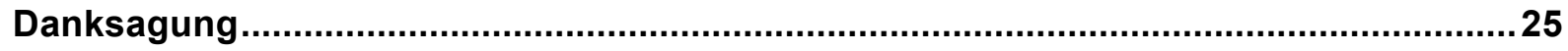

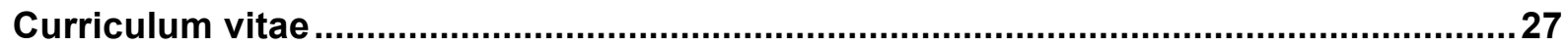

The following text is published in Veterinary Pathology:

M. Dettwiler, M. Croci, L. Vaughan, F. Guscetti. Immunohistochemical Expression Study of Proapoptotic BH3-only Protein Bad in Canine Nonneoplastic Tissues and Canine Lymphomas. Vet Pathol 2013, Vol 50(5), pp. 789-796, doi: 10.1177/0300985813478212. 


\title{
Immunohistochemical expression study of pro-apoptotic BH3-only protein Bad in canine non-neoplastic tissues and canine lymphomas
}

\begin{abstract}
The $\mathrm{BH} 3-$ only protein $\mathrm{Bad}$ is a pro-apoptotic $\mathrm{Bcl}-2$ family member that acts as a sensitizer in intrinsic apoptosis by inactivating anti-apoptotic members through heterodimer formation. Bad has been shown to contribute to tumorigenesis including lymphoma formation in humans and mice through alteration in expression and/or functional status. Here, its immunohistochemical expression was analyzed in canine non-neoplastic and lymphoma tissues using tissue microarrays. Bad was expressed in the cytoplasm of a wide range of non-neoplastic tissues, especially epithelial cells. Non-neoplastic lymph nodes displayed weak immunostaining in the follicular germinal centers only. Immunoblotting supported these observations, but also revealed presence of non-specific labeling in some organs. Twentynine of 81 lymphomas (35.8\%) displayed moderate to strong immunohistochemical Bad labeling, and a significant expression increase was found in lymphomas (especially B-cell and double negative) compared to non-neoplastic lymph nodes. These findings warrant further investigations of the functional status, the involvement of partner proteins and a possible impact of Bad on prognosis in canine lymphoma.
\end{abstract}

Key words

Bad; Bcl-2 family; dog; immunohistochemistry; lymphoma; protein expression; tissue microarray (TMA); western blot 


\section{Introduction}

Apoptosis is essential for normal development and tissue homeostasis and protects against diseases including cancer. ${ }^{3}$ Several members of the Bcl-2 family proteins, which are critical regulators of intrinsic apoptosis, have been assigned either oncogenic or tumor suppressor properties. $^{2}$ The pro-apoptotic BH3-only subgroup member Bad (Bcl- $\mathrm{X}_{\mathrm{L}} / \mathrm{Bcl}-2$ associated death promoter) acts as a sensitizer early in the course of intrinsic apoptosis by binding and neutralizing its anti-apoptotic partners $\mathrm{Bcl}-2, \mathrm{Bcl}-\mathrm{X}_{\mathrm{L}}$ and $\mathrm{Bcl}-\mathrm{w}^{1,16}$ This binding is inhibited by phosphorylation of Bad at conserved serine residues which leads to the inactivation of Bad through sequestration by cytosolic $14-3-3$ proteins. ${ }^{4,11,18}$

Ablation of Bad in mice induced diffuse large B-cell lymphomas ${ }^{10}$ and loss of Bad expression was observed in spontaneous epidermal neoplasms in humans. ${ }^{13}$ Increased levels of phosphorylated Bad were found in follicular lymphomas and colorectal carcinomas. ${ }^{7,17}$ Publicly available immunohistochemical data indicate that Bad is widely expressed in normal human organs. ${ }^{8,12}$ In some tissues including lymphatic organs and a limited number of lymphoma cell lines and lymphoma samples, expression levels of Bad appeared to be low or even absent. $^{8,12}$

Due to the apparent lack of canine data, the aim of the present study was to assess the expression of Bad in non-neoplastic tissues and lymphomas in this species by means of immunohistochemistry.

\section{Material and Methods}

\section{Canine tissues and cultured cells}

Tissues. Tissue microarrays (TMAs) containing archival canine non-neoplastic organs (Table 1) were available from a previous study. ${ }^{14}$ In addition, normal, non-neoplastic mandibular lymph node samples were available; they comprised a TMA containing six to ten $1.2 \mathrm{~mm}$ cores from each of 18 dogs and a multi-block containing larger lymph node probes from seven further dogs. Selected normal tissues were freshly collected and snap-frozen for western blot analysis. TMAs containing four cores of $0.6 \mathrm{~mm}$ diameter each from 90 cases of canine lymphoma immunophenotyped and classified were available from previous studies. ${ }^{5,14}$ Representativeness of cores was assessed on consecutive sections labeled with HE and with immunohistochemical CD3 and CD79 acy markers as described. ${ }^{14}$

Canine T-cell lymphoma CL-1 cells. The cells were cultured in RPMI 1640 medium with stable glutamine (E15-885, PAA Laboratories, Pasching, Austria) supplemented with fetal calf serum 10\% (BioConcept Ltd., Allschwil, Switzerland) and penicillin/streptomycin 1\% (Gibco BRL Life Sciences, Basel, Switzerland) under standard conditions. Pellets were constructed for immunohistochemistry as described using cells fixed for $24 \mathrm{~h}$ in $4 \%$ 
formaldehyde. ${ }^{6}$ For western blot analysis, the cells were washed with ice cold PBS and pelleted in $15 \mathrm{ml}$ tubes at $6000 \mathrm{~g}$ for $2 \mathrm{~min}$ at $4{ }^{\circ} \mathrm{C}$. The supernatant was discarded, the pellet was resuspended in PBS, and centrifuged at $16000 \mathrm{~g}$ for $1 \mathrm{~min}$ at $4{ }^{\circ} \mathrm{C}$ in a $1.5 \mathrm{ml}$ Eppendorf tube. The pelleted cells were lysed in ice-cold lysis buffer (20 mM Tris, $100 \mathrm{mM}$ $\mathrm{NaCl}, 1 \mathrm{mM}$ EDTA, $0.5 \%$ Triton $\mathrm{X}$ ) supplemented with protease inhibitors (1 mM PMSF, 0.3 $\mu \mathrm{M}$ Aprotinin, $0.5 \%$ Leupeptin, $0.01 \%$ Pepstatin-A), centrifuged at $16000 \mathrm{~g}$ for $15 \mathrm{~min}$ at $4{ }^{\circ} \mathrm{C}$ and the supernatant was stored at $4{ }^{\circ} \mathrm{C}$ until further processing.

\section{Immunohistochemistry}

Sections $(2 \mu \mathrm{m})$ were mounted on positively charged glass slides and immunostained in a Discovery XT autostainer (Ventana Medical Systems, Inc., Tucson AZ, USA) using the CC1 antigen retrieval program and the monoclonal antibody 1541-1 against human Bad (Epitomics, Burlingame CA, USA) in a 1:1500 dilution. The immunohistochemical procedure as well as the antibody selection and validation process, which relied on the use of canine recombinant Bad protein and of UV-irradiated canine keratinocytes, are extensively described in the supplementary material. Negative controls using 1\% BSA in PBS instead of the primary antibody were carried out for each section. All tissues were scored according to the cytoplasmic immunohistochemical signal intensity as follows: $0=$ signal absent, $1=$ weak, 2 = moderate, 3 = strong signal. The score assigned to a given cell type corresponded to the signal intensity displayed by more than $50 \%$ of the cells. The reported final scores for each cell type were calculated as mean values of two independent readings by one author (MD). For a lymphoma case to be scored, presence of at least two properly labeled representative cores with more than $50 \%$ of the core well preserved was required. A mean score for all cores of each tumor was calculated. The immunohistochemical signal intensity scores of B-cell, T-cell, and double negative (DN) lymphoma immunophenotypes and of the non-neoplastic lymph nodes $(n=26)$ were compared statistically using the non-parametric Kruskal-Wallis-rank sum test and Dunn's post hoc z-value test. P-values lower than 0.05 (zvalues $>2.638$ ) were considered to indicate statistical significance. Analyses were performed using SPSS (Version 20, SPSS Inc, Chicago IL, USA).

\section{Western Blots}

Tissue pieces (approx. $200 \mathrm{mg}$ ) were thawed, lysed in $1.5 \mathrm{ml}$ lysis buffer (15 mM HEPES pH $7.5,15 \mathrm{mM} \mathrm{NaCl}, 60 \mathrm{mM} \mathrm{KCl}, 0.27 \mathrm{M}$ sucrose, $2 \mathrm{mM}$ EDTA pH 8.0, 1\% Triton-X, protease inhibitors as above) using a pestle, and centrifuged three times at $16000 \mathrm{~g}$ for $15 \mathrm{~min}$ at 4 ${ }^{\circ} \mathrm{C}$. Lysates of tissues (containing $100 \mu \mathrm{g}$ of protein as determined with the Bradford method) and of CL-1 cells $(18 \mu \mathrm{g}$, measured using a NanoDrop-1000 (Thermo Fisher Scientific, Wilmington, DE, USA)) were loaded with $4 x$ SDS loading buffer $(0.25 \mathrm{M} \mathrm{Tris} / \mathrm{HCl} \mathrm{pH} \mathrm{6.8,8 \%}$ SDS, $10 \%$ glycerol, $0.02 \%$ bromphenol blue, $10 \% \quad \beta$-mercaptoethanol) on a $12 \%$ 
polyacrylamide gel and blotted (Fastblot B43, Biometra GmbH, Göttingen, Germany) onto a PVDF membrane (Immobilon-P Transfer Membrane, Millipore Corporation, Billerica MA, USA). After blocking with 3\% BSA in TBST (Dako Wash Buffer 10x, Dako Schweiz AG, Baar, Switzerland), membranes were incubated with antibody 1541-1 (Epitomics) diluted 1:5000, washed with TBST, incubated with a horseradish peroxidase-conjugated polyclonal goatanti-rabbit antibody (Jackson ImmunoResearch, Soham, UK) diluted 1:10 000, washed, incubated with LumiGLO (Kirkegaard \& Perry Laboratories Inc., Gaithersburg MD, USA) and developed on an enhanced chemiluminiscence film (Amersham Hyperfilm ECL, GE Healthcare Limited, Buckinghamshire, UK). For negative control, 1\% BSA in TBST was used instead of the primary antibody.

\section{Results}

This study analyzed immunohistochemically the expression of Bad in canine non-neoplastic tissues and lymphomas assembled in TMAs using an extensively validated monoclonal antibody (see Supplementary Material). The results were partially corroborated by western blot analyses.

\section{Non-neoplastic tissues}

The immunohistochemical signal (Table 1, Figs. 1 to 11) was limited to the cell cytoplasm. It was either diffusely homogeneous or coarsely granular, except for cells of the exocrine pancreas and adrenal medulla, where it appeared as well demarcated, large, intensely labeled granules, or as large, empty vesicles, respectively. Several organs and cell types displayed weak to moderate labeling intensities. A strong labeling was generally present in exocrine pancreas cells (Fig. 4), renal proximal tubular epithelium (Fig. 5), spermatids (Fig. 7 ) and the tracheal epithelium. Labeling was completely absent from superficial epidermal cells (granular and cornified layer), fibrous tissues, and striated muscles (Fig. 9), and from all negative controls. Cores from different dogs often displayed small differences in signal intensities (Table 1). Rare cell types with interindividual differences greater than one score point included small intestinal enterocytes and prostatic epithelial cells. In non-neoplastic lymph nodes immunohistochemical labeling of lymphocytes was in general mainly restricted to germinal center lymphocytes (score 1), while mantle and interfollicular zones were negative (Figs. 10a and 10b). 
Table 1. Immunohistochemical detection of Bad in non-neoplastic canine tissues (continued next page).

\begin{tabular}{|c|c|c|c|}
\hline Organ / tissue & Cell type & Signal intensity $^{a}$ & Signal pattern $^{b}$ \\
\hline \multirow[t]{3}{*}{ Epidermis } & Basal cell layer & $1-2$ & $\mathrm{DH}$ \\
\hline & Spinous layer & 1 & $\mathrm{DH}$ \\
\hline & Granular \& cornified layer & 0 & - \\
\hline Fibrous tissue & Fibrocytes & 0 & - \\
\hline Skeletal muscle & Myocytes & 0 & - \\
\hline Smooth muscle & Myocytes & $0-1$ & $\mathrm{DH}$ \\
\hline Heart & Myocardium & $0-1$ & $\mathrm{DH}$ \\
\hline Vessels & Endothelium & 1 & $\mathrm{DH}$ \\
\hline \multirow[t]{4}{*}{ Trachea \& lung } & Respiratory epithelium & $2-3$ & $\mathrm{DH}$ \\
\hline & Chondrocytes & 1 & $\mathrm{DH}$ \\
\hline & Pneumocytes & $0-1$ & $\mathrm{DH}$ \\
\hline & Alveolar macrophages & $1-2$ & DG \\
\hline Salivary glands & Secretory cells & $0-1$ & $\mathrm{DH}$ \\
\hline Esophagus & Epithelium & 1 & $\mathrm{DH}$ \\
\hline \multirow[t]{2}{*}{ Stomach } & Parietal cells & 2 & DG \\
\hline & Chief cells & 1 & $\mathrm{DH}$ \\
\hline Intestine & Enterocytes (villi \& crypts) & $1-3$ & DG \\
\hline Liver & Hepatocytes & $1-2$ & DG \\
\hline \multirow[t]{2}{*}{ Pancreas } & Exocrine cells & $2-3$ & LG \\
\hline & Islets of Langerhans & 1 & DG \\
\hline \multirow[t]{3}{*}{ Kidney } & Glomeruli & $0-1$ & $\mathrm{DH}$ \\
\hline & Proximal tubules & $2-3$ & DG \\
\hline & Distal tubules & $1-2$ & DG \\
\hline Bladder & Epithelium & 1 & $\mathrm{DH}$ \\
\hline \multirow[t]{2}{*}{ Ovary } & Germinal epithelium & $1-2$ & $\mathrm{DH}$ \\
\hline & Corpus luteum & 2 & $\mathrm{DH}$ \\
\hline Uterus & Endometrium & $1-2$ & $\mathrm{DH}$ \\
\hline Vagina & Epithelium & $1-2$ & $\mathrm{DH}$ \\
\hline Mammary gland & Epithelium & 1 & $\mathrm{DH}$ \\
\hline Prostate gland & Epithelium & $0-2$ & $\mathrm{DH}$ \\
\hline \multirow[t]{6}{*}{ Testis } & Spermatogonia & $1-2$ & DG \\
\hline & Spermatocytes & $2-3$ & DG \\
\hline & Spermatids & 3 & DG \\
\hline & Spermatozoa & $1-2$ & DG \\
\hline & Sertoli cells & $1-2$ & DG \\
\hline & Leydig cells & 1 & DG \\
\hline
\end{tabular}


Table 1. (continued)

\begin{tabular}{|c|c|c|c|}
\hline Spleen $^{c}$ & Red pulp & $0-1$ & $\mathrm{DH}$ \\
\hline \multirow[t]{4}{*}{ Tonsil \& lymph node } & Follicular germinal center & $1-2$ & $\mathrm{DH}$ \\
\hline & Mantle zone & $0-1$ & $\mathrm{DH}$ \\
\hline & Interfollicular regions & 0 & - \\
\hline & Plasma cells & $2-3$ & $\mathrm{DH}$ \\
\hline Thymus & Cortex and medulla & $0-1$ & $\mathrm{DH}$ \\
\hline \multirow[t]{3}{*}{ Bone marrow } & Myeloid precursors & $0-1$ & $\mathrm{DH}$ \\
\hline & Erythrocyte precursors & $2-3$ & $\mathrm{DH}$ \\
\hline & Megakaryocytes & $0-1$ & $\mathrm{DH}$ \\
\hline \multirow[t]{2}{*}{ Adrenal gland } & Cortex & 1 & $\mathrm{DH}$ \\
\hline & Medulla & 2 & $\mathrm{~V}$ \\
\hline Thyroid gland & Follicular epithelium & $1-2$ & DG \\
\hline Parathyroid gland & Epithelium & $1-2$ & DG \\
\hline \multirow[t]{4}{*}{ Cerebral cortex } & Large neurons & $1-2$ & $\mathrm{DH}$ \\
\hline & Neuropil & $0-1$ & $\mathrm{DH}$ \\
\hline & Neuroglia & $0-1$ & $\mathrm{DH}$ \\
\hline & Axons in white matter & 2 & $\mathrm{DH}$ \\
\hline \multirow[t]{2}{*}{ Cerebellum } & Purkinje cells & $1-2$ & $\mathrm{DH}$ \\
\hline & Axons in granular layer & 2 & $\mathrm{DH}$ \\
\hline \multirow[t]{4}{*}{ Spinal cord } & Neurons & 1 & $\mathrm{DH}$ \\
\hline & Neuroglia & $0-1$ & $\mathrm{DH}$ \\
\hline & Neuropil & $0-1$ & $\mathrm{DH}$ \\
\hline & Ependyme & $1-2$ & $\mathrm{DH}$ \\
\hline
\end{tabular}

\footnotetext{
${ }^{\text {a }}$ Signal intensity score: 0 = absent; 1 = weak; 2 = moderate; 3 = strong. A range of score values denotes interindividual differences.

${ }^{\mathrm{b}}$ Cytoplasmic signal distribution: $\mathrm{DH}=$ diffusely homogeneous; $\mathrm{DG}=$ diffusely granular; $\mathrm{LG}=$ large demarcated granules; $\mathrm{V}=\mathrm{vesicular}$

${ }^{\mathrm{c}}$ White pulp not present in available cores.
} 


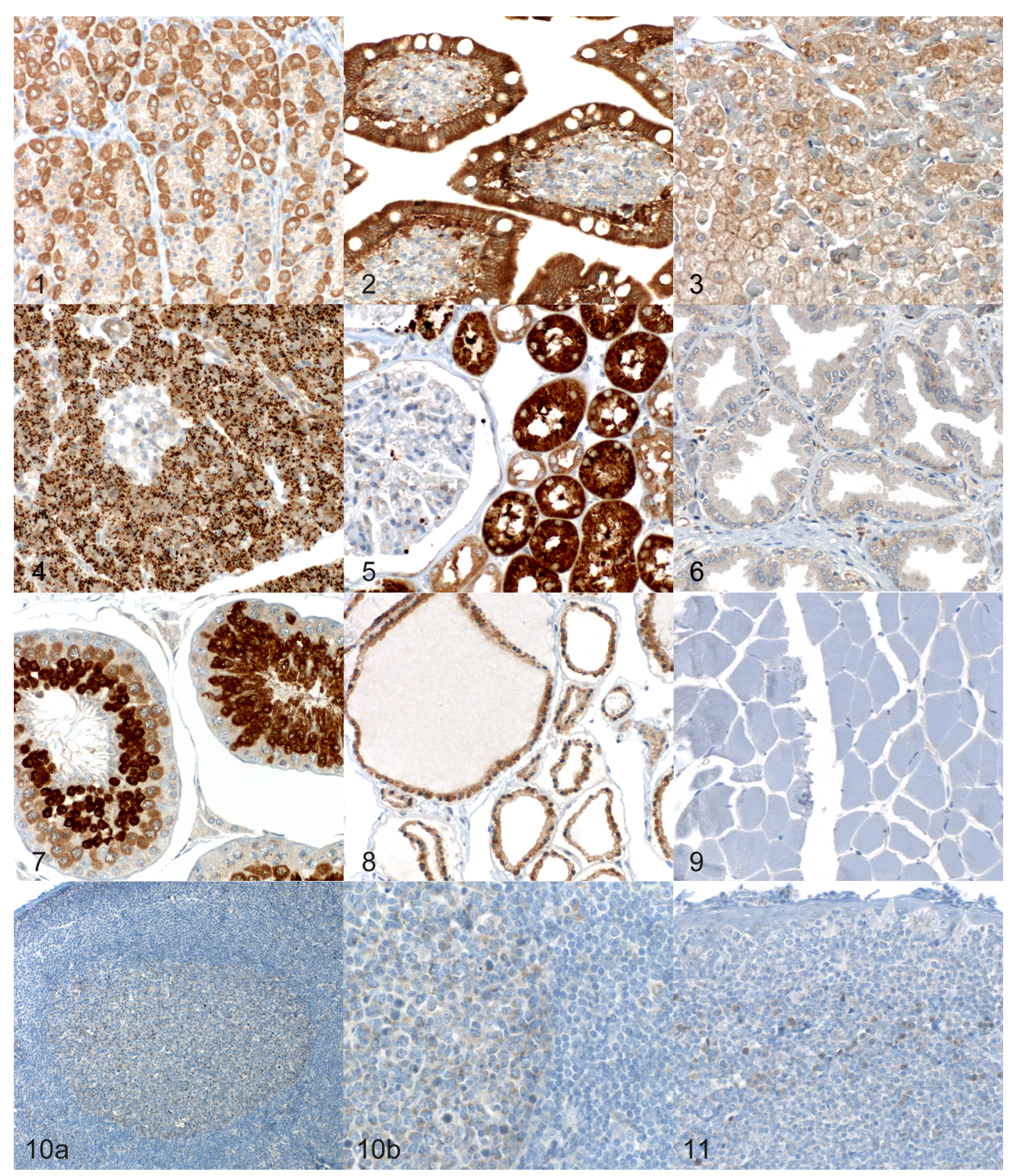

Figures 1-11. Immunohistochemical Bad labeling of non-neoplastic canine tissues (each from a different dog). The immunohistochemical signal was limited to the cytoplasm. Anti-Bad antibody 15411, detection with Omni-UltraMap, hematoxylin counterstain. Figure 1. Stomach. Gastric mucosa with granularly labeled parietal cells (signal intensity score 2) and homogeneously labeled chief cells (score 1). Figure 2. Small intestine. Villi with granularly labeled enterocytes (score 3). Figure 3. Liver. Hepatocytes with granular labeling (score 2). Figure 4. Pancreas. Strongly labeled demarcated granules in exocrine cells (score 3 ) and weakly labeled islets of Langerhans (score 1). Figure 5. Kidney. Renal cortex with granularly labeled proximal tubuli (score 3), granularly labeled distal tubuli (score 2), and homogeneously labeled glomeruli (score 1). Figure 6. Prostate gland. Homogeneously labeled epithelium (score 1). Figure 7. Testis. Slightly labeled spermatogonia and Sertoli cells (score 1), granularly labeled spermatocytes (score 2), homogeneously labeled spermatids (score 3 ), slightly labeled spermatozoa (score 1), and slightly labeled Leydig's cells (score 1). Figure 8. Thyroid gland. Granularly labeled follicular epithelium (score 2). (Continued next page.) 
(Figure legend continued:) Figure 9. Skeletal muscle. Unlabeled myocytes. Figure 10a. Lymph node. Weakly labeled germinal center lymphocytes, and unlabeled mantle zone and interfollicular region lymphocytes. Figure 10b. Lymph node, higher magnification. Germinal center lymphocytes with homogeneous labeling (score 1). Figure 11. Tonsil. Homogeneously labeled plasma cells (score 2) and unlabeled lymphocytes.

Western blots run for Bad with lysates of selected non-neoplastic tissues to test the reliability of immunohistochemistry (Fig. 12) showed, in general, overall intensities matching well with the immunohistochemical signals. However, kidney, pancreas, and liver lysates showed, besides the expected single band at $21 \mathrm{kDa}$ or double band at 21 and $18 \mathrm{kDa}$, one or two additional, prominent, likely non-specific bands at 40 and $50 \mathrm{kDa}$. In contrast, the major product labeled by the antibody in extracts of normal lymphatic tissues and testis had the expected size.

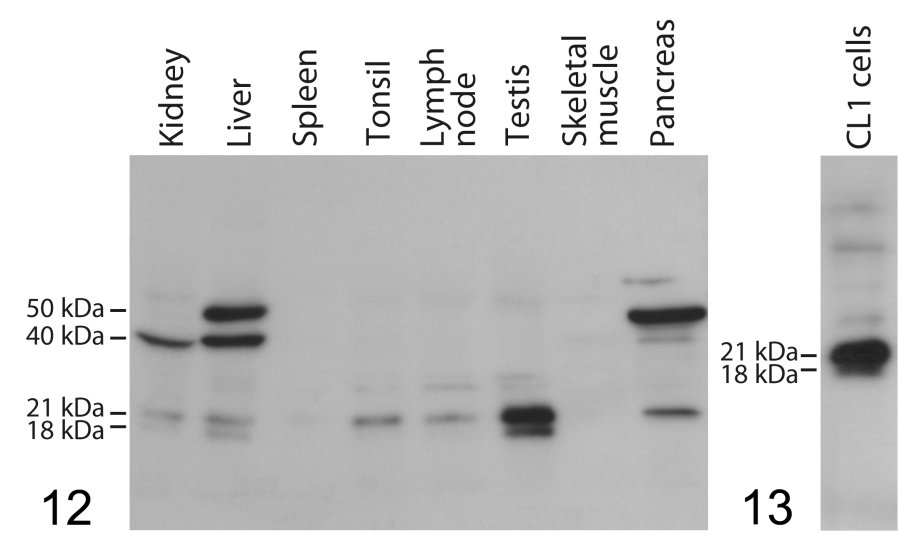

Figure 12. Western blot for Bad with antibody 1541-1 in non-neoplastic tissue lysates of indicated organs. Distinct bands compatible with Bad at $21 \mathrm{kDa}$ and partly also at $18 \mathrm{kDa}$ are present in liver, kidney, tonsil, lymph node, testis and pancreas lysates; liver, kidney and pancreas lysates show additional prominent bands at 40 and/or $50 \mathrm{kDa}$.

Figure 13. Western blot for Bad with antibody 1541-1 in CL-1 lymphoma cell lysates. Two bands of expected size are very prominently labeled.

\section{Lymphomas}

Bad immunohistochemistry of CL-1 lymphoma cells resulted in a generalized, marked cytoplasmic signal (Fig. 14), while a western blot showed exclusive labeling of a double band of $21 \mathrm{kDa}$ (major product) and $18 \mathrm{kDa}$ (Fig. 13) supporting specificity of the antibody. Neoplastic cells of the 81 cases fulfilling the inclusion criteria predominantly displayed a diffusely homogeneous cytoplasmic signal, with a superimposed granulated pattern observed in a few cases. Overall, the lymphoma cases showed scores ranging from 0 to 3 (Figs. 15 to 18 ) with a mean value of 1.08 , a median value of 1.00 and a standard deviation of 0.73 . The labeling intensity varied very little within cores, while in about $50 \%$ of the lymphoma cases a slight inter-core variability of up to maximally one scoring point (in one single case two points) was noted. Table 2 lists the scoring results of the lymphoma cases grouped according to immunophenotype and most frequent subtypes, as well as of all normal lymph 
node tissues available on TMAs. While most non-neoplastic lymph nodes (25 of $26,96.2 \%$ ) displayed an overall signal intensity score $\leq 1$, this applied to only 52 of $81(64.2 \%)$ lymphoma cases. The remaining 29 cases (comprising 17 B-cell, 4 T-cell and 8 DN lymphomas) showed scores $>1$. Among B-cell lymphomas, the heterogeneous group with less common subtypes and not classifiable lymphomas displayed higher signal intensities than the other groups. One-way analysis of variance with the Kruskal-Wallis rank sum test showed a statistically significant difference in the labeling intensity between non-neoplastic lymph nodes and the whole group of lymphomas $(p<0.001)$. A Dunn's post hoc $z$-value test revealed a statistically significant difference between non-neoplastic lymph nodes and B-cell lymphomas $(z=3.602, p=0.002)$, between non-neoplastic lymph nodes and DN lymphomas $(z=4.557, p=0.001)$ and between T-cell lymphomas and DN lymphomas $(z=3.739, p=0.001)$.

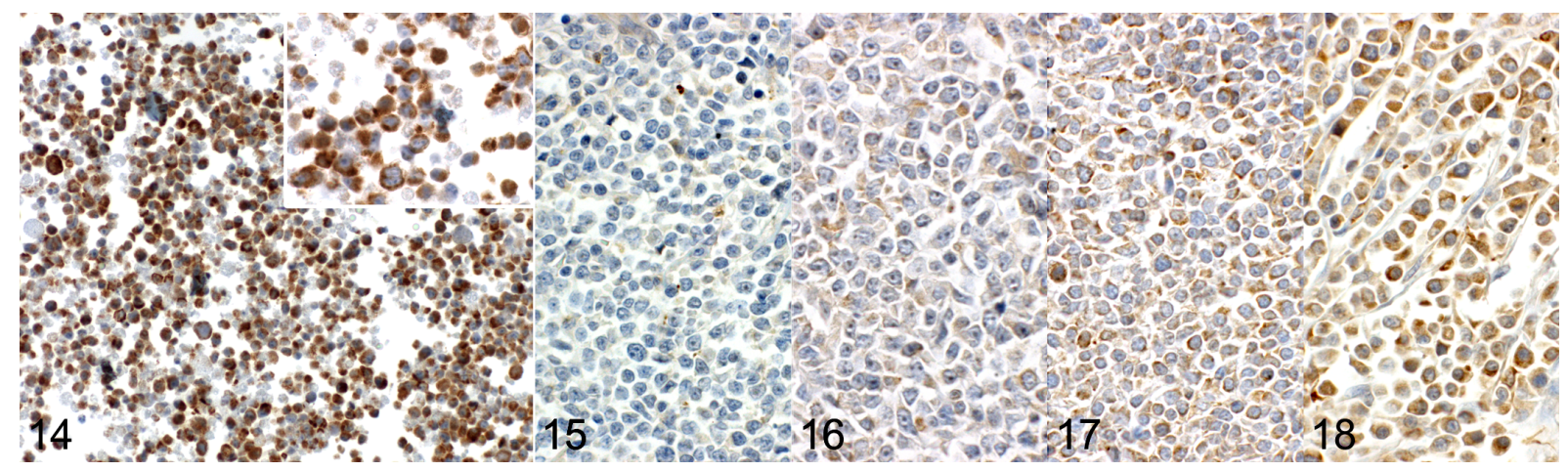

Figure 14-18. Immunohistochemical Bad labeling in canine lymphoma. Anti-Bad antibody 1541-1, detection with Omni-UltraMap, hematoxylin counterstain. Figure 14. Formalin-fixed and paraffin waxembedded CL-1 lymphoma cells displaying a strong cytoplasmic signal. Inset: Same cells at higher magnification. Figure 15. Lymphoma, case L53. Neoplastic cells showing signal intensity score 0. Figure 16. Lymphoma, case L7. Neoplastic cells showing score 1. Figure 17. Lymphoma, case L15. Neoplastic cells showing score 2. Figure 18. Lymphoma, case L88. Neoplastic cells showing score 3. 
Table 2. Immunohistochemical detection of Bad in canine lymphomas and non-neoplastic lymph nodes.

\begin{tabular}{|c|c|c|c|c|c|c|}
\hline \multicolumn{2}{|c|}{$\begin{array}{l}\text { Lymphoma subtype according to indicated } \\
\text { classification scheme }\end{array}$} & \multirow{2}{*}{$\begin{array}{c}\text { Total } \\
\text { number of } \\
\text { cases }\end{array}$} & \multicolumn{4}{|c|}{$\begin{array}{l}\text { Number of cases with indicated mean Bad } \\
\text { signal intensity score }{ }^{a}\end{array}$} \\
\hline Revised Kiel & REAL-WHO & & 0 & $\leq 1$ & $\leq 2$ & $\leq 3$ \\
\hline \multicolumn{7}{|l|}{ B-Immunophenotype $(n=48)$} \\
\hline Centroblastic monomorphic & Diffuse large B-cell & $10(12.4 \%)$ & $1(1.2 \%)$ & $8(9.9 \%)$ & $1(1.2 \%)$ & 0 \\
\hline Centroblastic polymorphic & Diffuse large B-cell & 15 (18.5\%) & 0 & $13(16.0 \%)$ & $2(2.5 \%)$ & 0 \\
\hline Marginal zone & Marginal zone & $10(12.4 \%)$ & $1(1.2 \%)$ & $5(6.2 \%)$ & $4(5.0 \%)$ & 0 \\
\hline $\begin{array}{l}\text { Other subtypes / not } \\
\text { classifiable }\end{array}$ & & $13(16.0 \%)$ & 0 & $3(3.7 \%)$ & $7(8.6 \%)$ & $3(3.7 \%)$ \\
\hline \multicolumn{7}{|l|}{ T-Immunophenotype $(n=23)$} \\
\hline Pleomorphic (various sizes) & $\begin{array}{l}\text { Peripheral T-cell not } \\
\text { otherwise specified }\end{array}$ & $12(14.8 \%)$ & $3(3.7 \%)$ & $8(9.9 \%)$ & $1(1.2 \%)$ & 0 \\
\hline $\begin{array}{l}\text { Other subtypes / not } \\
\text { classifiable }\end{array}$ & & $11(13.6 \%)$ & $2(2.5 \%)$ & $6(7.4 \%)$ & $3(3.7 \%)$ & 0 \\
\hline \multicolumn{7}{|l|}{$\begin{array}{l}\text { Double-Negative } \\
\text { Immunopheno-type }(n=10)\end{array}$} \\
\hline High-grade, medium sized & & $5(6.2 \%)$ & 0 & 0 & $3(3.7 \%)$ & $2(2.5 \%)$ \\
\hline $\begin{array}{l}\text { Other subtypes / not } \\
\text { classifiable }\end{array}$ & & $5(6.2 \%)$ & 0 & $2(2.5 \%)$ & $2(2.5 \%)$ & $1(1.2 \%)$ \\
\hline Total lymphoma cases & & $81(100 \%)$ & $7(8.6 \%)$ & $45(55.6 \%)$ & $23(28.4 \%)$ & $6(7.4 \%)$ \\
\hline Non-neoplastic lymph nodes & & $26(100 \%)$ & $5(19.2 \%)$ & $20(77.0 \%)$ & $1(3.8 \%)$ & 0 \\
\hline
\end{tabular}

${ }^{\mathrm{a}}$ Signal intensity score: 0 = absent; 1 = weak; 2 = moderate; 3 = strong; a mean of all available cores was calculated for each case.

\section{Discussion}

The present study analyzed the expression of Bad protein in canine lymphomas. Since ablation of Bad was purported to promote lymphoma development in mice, ${ }^{10}$ a decreased Bad expression in canine lymphoma compared to non-neoplastic lymph nodes was considered as a possible outcome. However, no such finding was observed here. Instead, a considerable fraction of the lymphomas (35.8\%) showed higher Bad expression than nonneoplastic lymphocytes, a difference that was statistically significant for B-cell and DN lymphomas, possibly indicating enhanced apoptotic signaling in the affected tumors. These findings contrast with the results of previous human studies showing little or no Bad expression in seven lymphoma and leukemia cell lines ${ }^{8}$ and in 20 of 22 malignant lymphomas. ${ }^{12}$ However, another report indicated higher Bad expression levels in diffuse large B-cell lymphomas compared to follicular and mantle cell lymphomas. ${ }^{15}$ Unfortunately, the number of cases in the present canine study was too small to assess statistical differences between subtypes. Moreover, there was no relationship between Bad expression and markers of apoptotic activity such as cleaved caspase-3 or cleaved lamin A in our material (unpublished data). This can be considered as an additional argument against a 
prominent role of Bad in the genesis of canine lymphoma. Since execution of intrinsic apoptosis is thought to depend on stoichiometric interactions of $\mathrm{Bcl}-2$ family members, the role of this protein might be more precisely assessed with a comprehensive approach probing the whole family.

Two reports indicate the presence of phosphorylated Bad in human follicular and cutaneous T-cell lymphomas. ${ }^{17,19}$ Thus, it might be of interest to determine the functional status of Bad in future studies, which was omitted here due to failure to find a suitable phosphorylation specific antibody (data not shown). However, the diffusely homogeneous signal observed in the canine tumors suggests that the enhanced signal may be due to an increase of inactive hyperphosphorylated Bad, which is sequestered in the cytoplasm by the scaffold protein 143-3. An involvement of Bad has been hypothesized in the development of chemotherapy resistance in human diffuse large B-cell lymphomas found to overexpress the isoform 14-3$3 \zeta^{9}{ }^{9}$

The other main part of this investigation was the analysis of Bad expression in nonneoplastic tissues. Western blot and immunohistochemical data indicate that Bad is expressed in the cytoplasm of a wide range of normal canine cell types. This is consistent with investigations of human tissues. ${ }^{8,12}$ However, western blot results indicate that the immunohistochemical findings in this broad tissue collection should be interpreted with caution, since in some organs, such as liver, kidney and pancreas, additional non-specific bands were present. There is no reported evidence for homodimerization of Bad, ${ }^{18}$ and the reducing conditions of the SDS-PAGE used here should have separated heterodimers as well. Thus, the marked immunohistochemical signal observed in these three organs has a major non-specific component. Interestingly, the immunohistochemical labeling pattern in the exocrine pancreas cells clearly differed from the either diffusely homogeneous or diffusely granular pattern observed in most other cell types. In summary, our data show the importance of validating antibodies with respect to their reactivity with the specifically targeted tissue or cell type. Specific immunohistochemical labeling of lymphomas in this study is supported by the lack of non-specific bands in lysates of non-neoplastic lymphatic tissues and, notably, of CL-1 lymphoma cells. However, validation by western blot is strongly advised for future prospective studies.

In general, similar to previous human studies, normal epithelial cells displayed a stronger signal than mesenchymal cells. ${ }^{8,12}$ Findings in several mesenchymal tissues including all types of musculature differed to some extent between human studies, thus hampering the interpretation of the canine data for these cell types. In canine non-neoplastic lymph nodes, a weak to moderate immunohistochemical signal was mainly observed in the cytoplasm of germinal center lymphocytes, while mantle and interfollicular zone lymphocytes were negative, as previously observed by Kitada and colleagues. ${ }^{8}$ The Protein Atlas ${ }^{12}$ indicates a 
weak to moderate signal in lymphatic tissue depending on the antibody used. Common explanations for discrepancies between studies include use of different antibodies targeting different epitopes and even of different protocols, the occurrence of different isoforms, and differences in tissue fixation and processing. Further reasons, possibly applicable here, include interspecies differences, inter-individual variability, the small amounts of tissue provided by TMAs and non-specific antibody binding in certain tissues.

In conclusion, the present study showed that the pro-apoptotic Bcl-2 family member Bad is expressed in a wide range of normal canine tissues. Our findings indicate that the results of immunohistochemical studies should be interpreted with great caution and that accurate validation, e.g. through western blotting as in this study, is crucial to rule out non-specific cross-reactions. Expression levels of Bad were generally low in non-neoplastic canine lymphocytes, but they were increased in a portion of the lymphomas examined. The significance of this finding is unknown and further investigation of the functional state of Bad, involved partner proteins and a possible impact on prognosis is required.

\section{Acknowledgement}

We are very grateful to Sabina Wunderlin for excellent technical help. We thank Dr. Sonja Hartnack for support with the statistical analysis. We are indebted to Prof. EJ. Müller and Prof. MM. Suter, University of Berne, Switzerland, for providing the Bskin cell line and Dr. Y. Goto-Koshino, University of Tokyo, Japan, for providing the CL-1 cell line.

\section{Declaration of Conflicting Interests and Funding}

The authors declared that they had no potential conflicts of interest with respect to their authorship or the publication of this article. The authors received no financial support for the research, authorship and/or publication of this article.

\section{References}

1. Chen L, Willis SN, Wei A, et al. Differential targeting of prosurvival $\mathrm{Bcl}-2$ proteins by their BH3only ligands allows complementary apoptotic function. Mol Cell. 2005;17(3):393-403.

2. Cory $\mathrm{S}$ and Adams JM. The Bcl2 family: regulators of the cellular life-or-death switch. Nat Rev Cancer. 2002;2(9):647-656.

3. Danial NN and Korsmeyer SJ. Cell death: critical control points. Cell. 2004;116(2):205-219.

4. Datta SR, Katsov A, Hu L, et al. 14-3-3 proteins and survival kinases cooperate to inactivate BAD by BH3 domain phosphorylation. Mol Cell. 2000;6(1):41-51.

5. Keller SM, Keller BC, Grest $\mathrm{P}$, et al. Validation of tissue microarrays for immunohistochemical analyses of canine lymphomas. J Vet Diagn Invest. 2007;19(6):652-659. 
6. Keller SM, Schade B, Rickenbacher AB, et al. A comprehensive test system to identify suitable antibodies against p53 for immunohistochemical analysis of canine tissues. J Comp Pathol. 2007;137(1):59-70.

7. Khor TO, Gul YA, Ithnin $\mathrm{H}$, et al. Positive correlation between overexpression of phospho-BAD with phosphorylated Akt at serine 473 but not threonine 308 in colorectal carcinoma. Cancer Lett. 2004;210(2):139-150.

8. Kitada $S$, Krajewska $M$, Zhang $X$, et al. Expression and location of pro-apoptotic Bcl-2 family protein BAD in normal human tissues and tumor cell lines. Am J Pathol. 1998;152(1):51-61.

9. Maxwell SA, Li Z, Jaye D, et al. 14-3-3zeta mediates resistance of diffuse large B cell lymphoma to an anthracycline-based chemotherapeutic regimen. $J$ Biol Chem. 2009;284(33):22379-22389.

10. Ranger AM, Zha J, Harada $\mathrm{H}$, et al. Bad-deficient mice develop diffuse large $B$ cell lymphoma. Proc Natl Acad Sci U S A. 2003;100(16):9324-9329.

11. Tan $Y$, Demeter MR, Ruan $H$, et al. BAD Ser-155 phosphorylation regulates $B A D / B c l-X L$ interaction and cell survival. J Biol Chem. 2000;275(33):25865-25869.

12. The Human Protein Atlas. http://www.proteinatlas.org/ENSG00000002330.

13. Tomková H, Fujimoto W, Arata J. Expression pattern of the bcl-2 homologous protein bad in normal skin, psoriasis vulgaris and keratinocytic tumors. J Dermatol Sci. 2000;22(2):132-137.

14. Wimmershoff J, Polkinghorne A, Grest $\mathrm{P}$, et al. Immunohistochemical detection of survivin in canine lymphoma. J Comp Pathol. 2010;142(4):311-322.

15. Xerri L, Devilard E, Bouabdallah R, et al. Quantitative analysis detects ubiquitous expression of apoptotic regulators in B cell non-Hodgkin's Iymphomas. Leukemia. 1999;13(10):15481553.

16. Yang $\mathrm{E}$, Zha J, Jockel J, et al. Bad, a heterodimeric partner for $\mathrm{Bcl}-\mathrm{XL}$ and $\mathrm{Bcl}-2$, displaces Bax and promotes cell death. Cell. 1995;80(2):285-291.

17. Zha H, Raffeld M, Charboneau L, et al. Similarities of prosurvival signals in Bcl-2-positive and Bcl-2-negative follicular lymphomas identified by reverse phase protein array. Lab Invest. 2004;84(2):235-244.

18. Zha J, Harada $\mathrm{H}$, Yang $\mathrm{E}$, et al. Serine phosphorylation of death agonist BAD in response to survival factor results in binding to 14-3-3 not Bcl-X(L). Cell. 1996;87(4):619-628.

19. Zhang CL, Kamarashev J, Qin JZ, et al. Expression of apoptosis regulators in cutaneous Tcell lymphoma (CTCL) cells. J Pathol. 2003;200(2):249-254. 


\section{Supplementary material}

\section{Selection and validation of a commercially available antibody for immunohistochemical detection of Bad in canine tissues}

\section{Antibody selection}

Five commercially available antibodies against human or murine Bad (Table S1) were tested for cross-reactivity with canine Bad by western blotting and immunohistochemistry against fusion proteins consisting of N-terminal Glutathione-S-Transferase (GST, $27 \mathrm{kDa}$ ) and canine Bad (18 kDa) as well as other canine apoptosis-related proteins expressed in bacteria. In a western blot using canine GST-Bad, monoclonal rabbit antibody 1541-1 (Epitomics), which recognizes an N-terminal epitope of human Bad, labeled three major bands at 45, 35 and 25 kDa (Fig. S1a, left panel). The top band represents full-length GST-Bad, while the lower bands represent degradation products. In contrast, the antibody showed no reaction with lysates from bacteria expressing GST alone or GST-conjugated canine p53 or GSTconjugated canine Noxa. Polyclonal rabbit antibody JM-3030-100 (MBL International), which was raised against purified full-length murine Bad protein, labeled the 45 and $35 \mathrm{kDa}$ bands of GST-Bad equally strongly (Fig. S1a, right panel). This antibody displayed no reaction in western blots with the other canine GST fusion proteins (data not shown). Polyclonal rabbit antibody HPA028185 (Sigma-Aldrich) labeled the 45 and $35 \mathrm{kDa}$ bands only weakly and showed no reaction with the other canine GST fusion proteins (data not shown). No signal was detectable in western blots with polyclonal rabbit antibody NBP1-19451 (Novus Biologicals) or monoclonal mouse antibody sc-8044 (Santa Cruz). These results were confirmed using immunohistochemistry with an array of formalin-fixed and paraffin waxembedded bacteria expressing various canine GST-fusion proteins (Figs. S1b-e). Monoclonal rabbit antibody 1541-1 (Epitomics) displayed a strong signal against the GSTBad core, but showed no reactivity towards other GST fusion proteins (Fig. S1c). Polyclonal rabbit antibody JM-3030-100 (MBL International) showed a weak specific signal for GST-Bad (Fig. S1d). The remaining three antibodies labeled several GST fusion proteins with moderate intensity without labeling GST-Bad more strongly under any of the conditions tested, and were thus considered unspecific (Fig. S1e and data not shown).

In summary, antibody 1541-1 was considered the best reagent based on its intense, specific labeling of canine GST-Bad in both western blots and immunohistochemistry, and was selected for further analysis. 


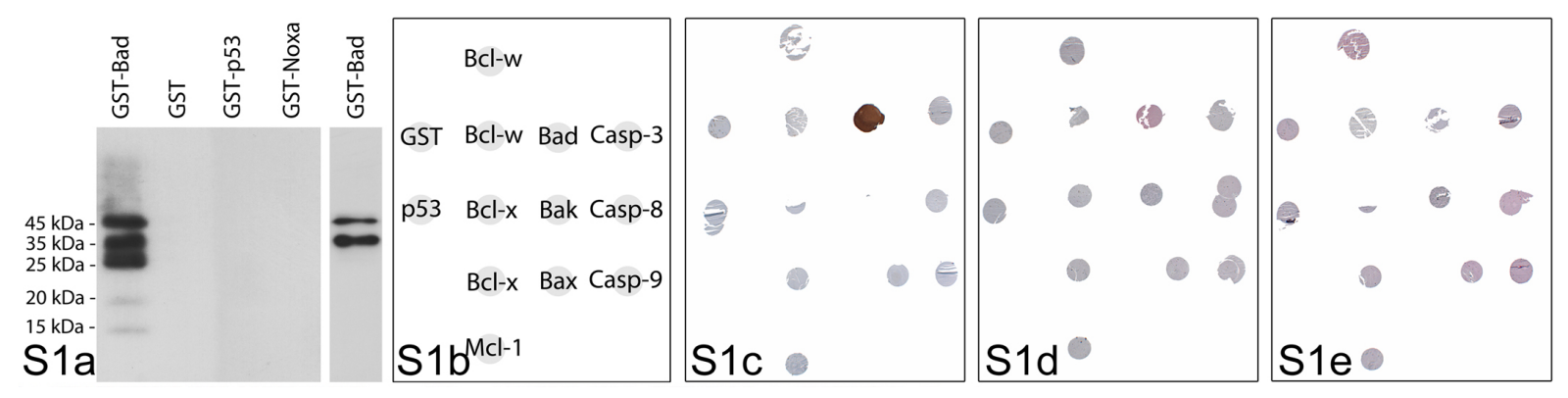

Figure S1. Evaluation of commercially available antibodies cross-reactivity and specificity for canine Bad using glutathione-S-transferase (GST) fusion proteins. Figure S1a. Western blot against indicated canine GST fusion proteins using antibody 1541-1 (left panel), and antibody JM-3030-100 (right panel). Figures S1b-e. Immunohistochemistry using bacterial pellet array containing formalinfixed, paraffin wax-embedded pelleted bacteria expressing canine GST fusion proteins. Figure S1b. Array design; Figure S1c. Immunohistochemistry with antibody 1541-1; only bacteria expressing GST-Bad are labeled; Figure S1d. Immunohistochemistry with antibody JM-3030-100; only bacteria expressing GST-Bad are weakly labeled; Figure S1e. Immunohistochemistry with antibody HPA028185; bacteria expressing various GST fusion proteins are unspecifically weakly labeled. Detection with Omni-UltraMap or RedMap, hematoxylin counterstain.

\section{Validation of antibody 1541-1}

A protocol was developed for the immunohistochemical detection of endogenous levels of Bad in canine cells using antibody 1541-1. Since the amount of Bad was expected to change in the course of intrinsic apoptosis, the antibody was tested with formalin-fixed and paraffin wax-embedded canine keratinocytes following UV-light irradiation (100 mJ). Most of the cells underwent cell death morphologically compatible with apoptosis and with extensive presence of cleaved caspase-3 (data not shown) within $24 \mathrm{~h}$ of treatment. Samples of each collection time were examined with immunohistochemistry and western blot (Figs. S2 and S3).

Non-irradiated control cells displayed a moderate degree of labeling with a finely stippled cytoplasmic distribution (Fig. S2a). In cells harvested at 30 minutes and $4 \mathrm{~h}$ post irradiation (p.i.), a mild diffuse increase of signal intensity compared to non-irradiated cells was observed (Figs. S2b and S2c). In addition, at $4 \mathrm{~h}$ p.i., single cells showing early signs of apoptosis were intensely labeled. At $8 \mathrm{~h}$ after irradiation, the intensity of the immunohistochemical signal was in most cells similar to the control sample, but an increasing number of cells, including some with early morphological signs of apoptosis such as nuclear swelling and membrane blebbing showed a marked perinuclear signal (Fig. S2d). Other apoptotic cells displayed a very weak labeling. At $12 \mathrm{~h}$ p.i., about two thirds of the keratinocytes had undergone apoptosis and showed weak or no labeling (Fig. S2e). The signal in the remaining viable cells was weak to moderate with a diffuse cytoplasmic to perinuclear distribution. At $24 \mathrm{~h}$ p.i., the signal had further decreased in intensity and was present as weak perinuclear labeling in the cells that had remained intact (Fig. S2f). A western blot using materials collected in the same experiment showed presence of a major 
band at $21 \mathrm{kDa}$ in all samples and of a moderate to weak band at $18 \mathrm{kDa}$, which almost disappeared at $12 \mathrm{~h}$ and $24 \mathrm{~h}$ p.i. (Fig. S3a, upper panel). This likely represents the previously described double band of hyperphosphorylated (upper band) and non- or hypophosphorylated Bad (lower band). ${ }^{18}$ The identity of the $21 \mathrm{kDa}$ band as canine Bad was confirmed in a western blot using antibody JM-3030-100 (data not shown). The sum of the signal intensities of both Bad-specific bands, relative (antibody 1541-1) to the $\beta$-actin band as a loading control (Fig. S3a, lower panel), indicates an initial increase in Bad expression up to 4-8 h, followed by a steady decrease through 12-24 h after UV-irradiation (Fig. S3b).

In conclusion, these results indicate that the protocol used is suitable for detecting endogenous levels of Bad in canine cells by immunohistochemistry and might, at least to some extent, detect variations in protein amounts. Therefore, the method was considered adequate for further analyses of the expression patterns of Bad in non-neoplastic canine tissues and canine lymphomas.
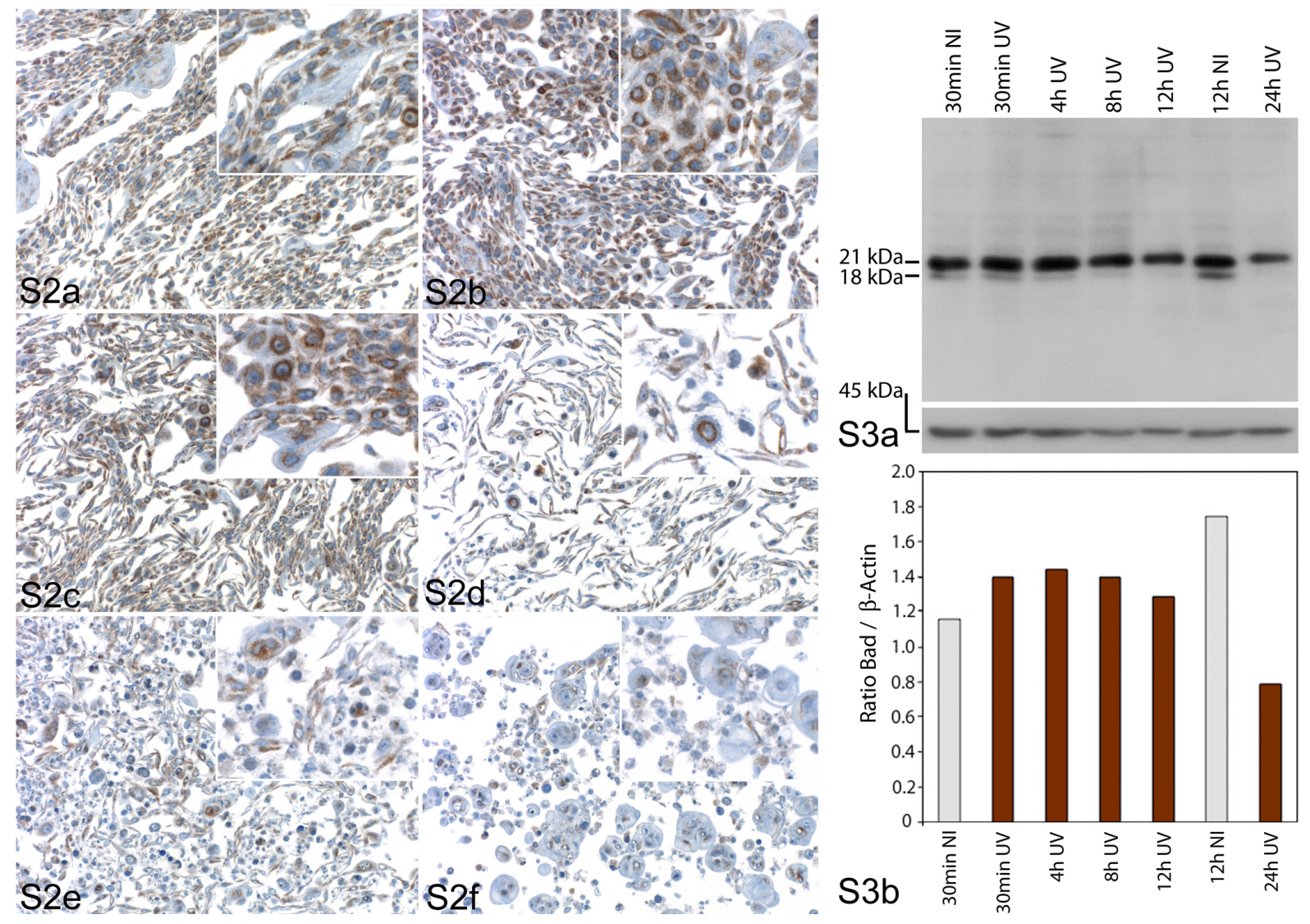

Figure S2. Immunohistochemical validation of anti-Bad antibody 1541-1 using cultured UV-irradiated canine keratinocytes. Figure S2a. Non-irradiated control at $30 \mathrm{~min}$; Figure S2b. Cells $30 \mathrm{~min}$ postirradiation (p.i.); Figure S2c. 4 h p.i.; Figure S2d. 8 h p.i.; Figure S2e. 12 h p.i.; Figure S2f. 24 h p.i.; cytoplasmic signal intensity appears to slightly increase $30 \mathrm{~min}$ and $4 \mathrm{~h}$ after UV-irradiation and to continuously decrease thereafter, especially in apoptotic cells; marked signs of apoptosis are present from $8 \mathrm{~h}$ post-irradiation and onwards. Detection with Omni-UltraMap, hematoxylin counterstain. (Continued next page.) 
(Figure legend continued:) Figure S3. Western blot validation of anti-Bad antibody 1541-1 using cultured UV-irradiated canine keratinocytes. Figure S3a. Upper panel: immunoblot using antibody 1541-1; lower panel: same membrane blotted with anti- $\beta$-actin antibody; Figure S3b. Intensities of Bad labeling of Figure S3a, upper panel, normalized to labeling for $\beta$-actin in Figure S3a, lower panel; lane and column labels indicate time after treatment $(\mathrm{NI}$, grey color = non-irradiated; UV, brown color = UV-irradiated); a band doublet of 21 and $18 \mathrm{kDa}$ corresponding to Bad is present in all lanes, quantitative analysis indicates an initial increase, then a decrease of Bad protein from $8 \mathrm{~h} \mathrm{p.i.} \mathrm{and}$ onwards.

\section{Material and methods}

Recombinant proteins. cDNAs of canine Bcl-2 family proteins ( $\mathrm{Bcl}-\mathrm{x}_{\mathrm{L}}, \mathrm{Bcl}-\mathrm{w}, \mathrm{Mcl}-1, \mathrm{Bak}, \mathrm{Bax}$, Noxa, Bad) and of other canine proteins involved in apoptosis ( $p 53$, caspase-3, caspase-8, caspase-9) cloned into a pGEX4t2 vector (Invitrogen, Carlsbad CA, USA) were available from either a previous study ${ }^{6}$ or from a concomitant study (manuscript in preparation). GenBank accession numbers of previously unreported canine sequences are as follows: Bclw: AAZ22484, Bak: AAY19401, Noxa: ABE02691, Bad: AAZ32936, Caspase-8: ABB02414, Caspase-9: AAZ22485. The plasmids were transformed into BL21 Star E. coli (Invitrogen) and the proteins were expressed as Glutathione-S-Transferase (GST) fusion proteins by isopropyl-beta-D-thiogalactopyranoside (IPTG, Sigma-Aldrich, Buchs, Switzerland) induction for $2.5 \mathrm{~h}$ as previously described. ${ }^{6}$ For immunohistochemical studies, induced bacterial cultures $(100 \mathrm{ml})$ were centrifuged at $4000 \mathrm{~g}$ for $10 \mathrm{~min}$ at $4{ }^{\circ} \mathrm{C}$, resuspended in $4 \%$ neutral buffered formaldehyde and fixed for $24 \mathrm{~h}$ at room temperature. Subsequently, the bacteria were pelleted and embedded in paraffin wax using the Cytoblock system (Thermo Shandon, Pittsburgh, PA, USA). ${ }^{6}$ A microarray with one $0.6 \mathrm{~mm}$ core of each protein-expressing bacterial pellet was assembled by means of a manual tissue arrayer and denominated bacterial pellet array (Beecher Instruments, Sun Prairie, USA). For western blot analysis, GST-Bad, GST-Noxa, GST-p53 and GST only were expressed in $500 \mathrm{ml}$ cultures of BL21 Star E. coli bacteria after induction with $1 \mathrm{mM}$ IPTG and purified using glutathione 4B Sepharose beads (GE Healthcare Bio-Sciences AB, Uppsala, Sweden) as previously described ${ }^{14}$ and stored at $-20^{\circ} \mathrm{C}$ until further processing.

UV-irradiated canine keratinocytes. Canine normal keratinocytes (Bskin, kindly donated by E. Müller and MM. Suter, Bern, Switzerland) were cultured at $37{ }^{\circ} \mathrm{C}$ and $\mathrm{v} / \mathrm{v} 5 \% \quad \mathrm{CO}_{2}$ in Dulbecco's Modified Eagles medium supplemented with non-essential amino acids 1\%, sodium pyruvate $1 \%$, penicillin/streptomycin 1\%, glutamax $1 \%$ (all reagents from Gibco BRL Life Sciences, Basel, Switzerland) and fetal calf serum 15\% (BioConcept Ltd., Allschwil, Switzerland). The cells were irradiated with $100 \mathrm{~mJ}$ UV light using an UV crosslinker with an emission peak at $254 \mathrm{~nm}$ (Hoefer UVC 500, Hoefer Inc., Holliston MA, USA) after replacing the medium with PBS. Irradiated and non-irradiated control cells were covered with cell 
culture medium again, cultured further and harvested $30 \mathrm{~min}, 4 \mathrm{~h}, 8 \mathrm{~h}, 12 \mathrm{~h}$ and $24 \mathrm{~h}$ after irradiation. Non-irradiated control cells were collected at time points corresponding to $30 \mathrm{~min}$ and $12 \mathrm{~h}$ after irradiation. Cells for each sampling time were cultured in duplicate in $75 \mathrm{~cm}^{2}$ cell culture dishes. For immunohistochemical assays, the cells were pelleted, fixed in buffered $4 \%$ formaldehyde for $24 \mathrm{~h}$ and embedded in paraffin wax as previously described. ${ }^{6}$ For western blot analysis, the cells were lysed as described for CL-1 cells in the main manuscript, and the lysate was stored at $4{ }^{\circ} \mathrm{C}$ until further processing.

Antibodies against Bad. Based on the canine Bad protein sequence deduced from our cDNA clone (GenBank accession number AAZ32936), five commercially available antibodies raised against human or murine Bad immunogens displaying the highest possible sequence homology (where appropriate) with the canine orthologue were identified. They are listed in Table S1 together with the relevant information including the tests in which they were used and the respective dilutions. Selling of antibody JM-3030-100 (MBL International, Woburn MA, USA) was discontinued by the manufacturer during this study.

Table S1. Commercially available antibodies used in this study.

\begin{tabular}{|c|c|c|c|c|c|c|c|c|}
\hline \multirow{3}{*}{ Catalogue no. } & \multirow{3}{*}{ Manufacturer } & \multirow{3}{*}{$\begin{array}{l}\text { Antibody } \\
\text { type }\end{array}$} & \multirow{3}{*}{ Immunogen } & \multirow{3}{*}{$\begin{array}{l}\text { Antibody } \\
\text { concentration }\end{array}$} & \multicolumn{4}{|c|}{ Dilutions in indicated test with indicated materials } \\
\hline & & & & & \multicolumn{2}{|c|}{ Western Blot } & \multicolumn{2}{|c|}{ Immunohistochemistry } \\
\hline & & & & & $\begin{array}{l}\text { Bead-bound } \\
\text { GST-proteins }\end{array}$ & $\begin{array}{l}\text { Cell culture / } \\
\text { tissue lysates }\end{array}$ & $\begin{array}{l}\text { Bacterial } \\
\text { pellets }\end{array}$ & $\begin{array}{l}\text { Cell pellets / } \\
\text { tissue arrays }\end{array}$ \\
\hline 1541-1 & Epitomics, Burlingame CA, USA & $m A b^{a}$ rabbit & $\begin{array}{l}\mathrm{aa}^{\mathrm{b}} 1-20 \text { of human } \\
\text { Bad }\end{array}$ & $\mathrm{NK}^{\mathrm{c}}$ & $1: 50000$ & $1: 5000$ & $1: 1000$ & 1:1500 \\
\hline$J M-3030-100^{d}$ & $\begin{array}{l}\text { MBL International, Woburn MA, } \\
\text { USA }\end{array}$ & $\mathrm{pAb}^{\mathrm{e}}$ rabbit & $\begin{array}{l}\text { full-length murine } \\
\text { Bad }\end{array}$ & $0.1 \mathrm{mg} / \mathrm{ml}$ & $1: 100$ & $1: 75$ & $1: 100$ & $N D^{f}$ \\
\hline NBP1-19451 & $\begin{array}{l}\text { Novus Biologicals, Cambridge, } \\
\text { UK }\end{array}$ & pAb rabbit & $\begin{array}{l}\text { aa } 110-160 \text { of } \\
\text { human Bad }\end{array}$ & $1.0 \mathrm{mg} / \mathrm{ml}$ & $1: 100-1: 750$ & ND & $1: 20-1: 100$ & ND \\
\hline sc-8044 & $\begin{array}{l}\text { Santa Cruz Biotechnology Inc, } \\
\text { Santa Cruz, USA }\end{array}$ & mAb mouse & $\begin{array}{l}\text { full-length human } \\
\text { Bad }\end{array}$ & $0.2 \mathrm{mg} / \mathrm{ml}$ & $1: 100-1: 500$ & ND & $1: 20-1: 1000$ & ND \\
\hline HPA 028185 & $\begin{array}{l}\text { Sigma Aldrich Co. LLC, St. Louis } \\
\text { MO, USA }\end{array}$ & pAb rabbit & $\begin{array}{l}\text { aa } 12-87 \text { of human } \\
\text { Bad }\end{array}$ & $0.1 \mathrm{mg} / \mathrm{ml}$ & $1: 100-1: 250$ & $1: 100$ & $1: 20-1: 100$ & ND \\
\hline
\end{tabular}

amino acid; ${ }^{\mathrm{b}}$ monoclonal antibody; ${ }^{\mathrm{C}}$ not known; ${ }^{\mathrm{d}}$ Manufacturer discontinued selling of this product during this study; ${ }^{\mathrm{e}}$ polyclonal antibody; ${ }^{\mathrm{i}}$ not done

Western Blots. Bacterially expressed, beads-bound GST fusion proteins were diluted with SDS loading buffer and processed as indicated in the main manuscript. Immunoblots were done using the antibodies listed in Table S1 as indicated in the main manuscript with the difference that a horseradish peroxidase-conjugated polyclonal goat-anti-mouse-HRP antibody (Geno Technologies, St. Louis MO, USA) was applied where appropriate. For each keratinocyte lysate sample $16 \mu \mathrm{g}$ were loaded with $4 x$ SDS loading buffer and processed using antibody $1541-1$ and JM-3030-100 (Table S1) and anti- $\beta$-actin monoclonal mouse antibody (ab8227, Abcam, Cambridge, UK) in a 1:3000 dilution. For negative control 1\% BSA in TBST was used instead of the primary antibody where appropriate. To calculate the ratio between Bad and $\beta$-actin the corresponding bands were scanned and the intensities of individual bands measured using the ImageJ program (http://rsb.info.nih.gov/ij/index.html). 
Immunohistochemistry using anti-Bad antibodies. The whole immunohistochemical procedure including the antigen retrieval was run in a Discovery XT autostainer (Ventana Medical Systems, Inc., Tucson AZ, USA) according to the manufacturer's instructions. The bacterial pellet array sections were pretreated either with citrate buffer $(\mathrm{pH} \mathrm{6.0,} \mathrm{CC2} \mathrm{cell}$ conditioning solution (950-123), Ventana) with the CC2 standard program (4x 8 min $98^{\circ} \mathrm{C}$ ), with Tris-based buffer ( $\mathrm{pH} 8.4$, CC1 cell conditioning solution (950-124), Ventana) with the CC1 standard program $\left(4 \times 8 \min 98^{\circ} \mathrm{C}\right)$ or with proteinase 1 (Ventana) for $8 \mathrm{~min}$. A fourth sample underwent no pretreatment. The antibody selection steps were carried out using all five commercially available antibodies, which were tested with all pretreatments at different dilutions varying from 1:20 to 1:1000 (Table S1). Incubation conditions with primary antibody were $1 \mathrm{~h}$ at $37^{\circ} \mathrm{C}$. A universal secondary antibody and the Omni-UltraMap and RedMap Detection Kits (Ventana) were used. With bacterial pellet arrays, an antibody was considered specific if the labeling of the core containing bacteria expressing GST-Bad was clearly distinguishable from that of all remaining cores. 


\section{Danksagung}

An dieser Stelle möchte ich mich bei allen bedanken, die zum Gelingen dieser Arbeit beigetragen haben:

Franco Guscetti für die Vergabe des spannenden Themas und die fachliche Betreuung.

Martina Croci und Lloyd Vaughan für die Unterstützung im Labor.

Sabina Wunderlin für ihre unverzichtbare Hilfe bei der Immunhistochemie.

Ein sehr grosser Dank gilt meinen Eltern, die mich immer unterstützt haben - insbesondere meinem Vater Max Dettwiler.

Und ein besonderer Dank geht an meine Freundin Laura Laschinger - einfach für alles. 


\section{Curriculum vitae}

Name, Vornamen: Dettwiler Martina Andrea

Geburtsdatum:

11.08.1981

Geburtsort:

Basel BS

Nationalität

Schweiz

Heimatort

Reigoldswil BL

$08 / 1988-06 / 1993$

Primarschule Birsfelden, Schweiz

08/1993-06/1997

Progymnasium Birsfelden, Schweiz

$08 / 1997-12 / 2000$

Gymnasium Muttenz, Schweiz

19.12 .2000

Matura Typus B (Latein), Gymnasium Muttenz, Schweiz

$09 / 2001-11 / 2006$

Studium Veterinärmedizin, Universität Zürich, Schweiz

03.11 .2006

Eidgenössisches Diplom Veterinärmedizin, Universität Zürich, Schweiz

$05 / 2007-10 / 2009$

Assistenztierärztin Gemischtpraxis, Tierarztpraxis Dres. Fürer und Spühler, Frauenfeld, Schweiz

$10 / 2007-12 / 2009$

Assistenztierärztin Gemischtpraxis, Tierarztpraxis Dres. Schär und Wick, Affeltrangen, Schweiz

$01 / 2010-02 / 2013$

Anfertigung der Dissertation unter Leitung von Prof. Dr. med. vet. Franco Guscetti am Institut für Veterinärpathologie der Vetsuisse Fakultät Zürich Direktor: Prof. Dr. med. vet. Andreas Pospischil

Zürich, 03.02.2013 